\title{
ANNUAL REPORTS
}

\section{REPORT OF THE TREASURER FOR THE YEAR 1911}

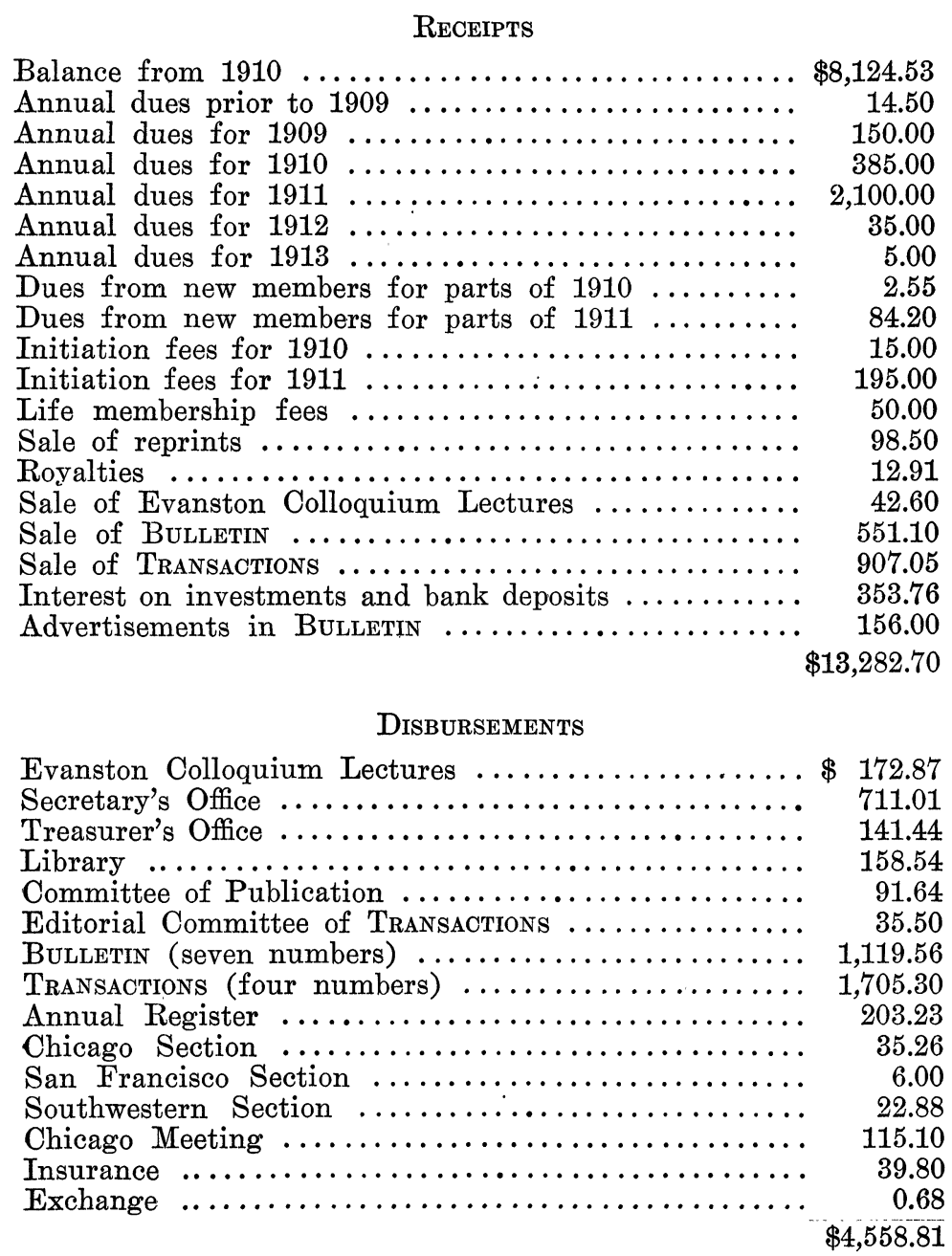


Investments (par value, $\$ 5,500.00$ ) ......\$5,259.50

Balance in First National Bank (Ithaca) .. 787.11

Balance in Union Square Savings Bank ... 1,623.87

Balance in Ithaca Savings Bank ........ 1,053.41

The Life Membership Fund now amounts to $\$ 4,137.17$.

J. H. TANNER,

IthaCA, N. Y., December 16, 1911.

Treasurer.

\section{REPORT OF THE AUDITING COMMITTEE}

The undersigned Auditing Committee, appointed by the American Mathematical Society, have this day examined the accounts of the Treasurer, compared them with the vouchers, bank-books, and securities, and find the following to be correct:

Balance from December $18,1910 \ldots \ldots \ldots \ldots \ldots \ldots \ldots \$$. . . . 124.53

Cash receipts since December 18, $1910 \ldots \ldots \ldots \ldots \ldots$. $5,158.17$

Balance in First National Bank (Ithaca) . \$ 787.11

Balance in Ithaca Savings Bank ........ 1,053.41

Balance in Union Square Savings Bank ... 1,623.87

Investments (par value, $\$ 5,500.00$ ) $\ldots \ldots \ldots$ 5,259.50

Disbursements since December 18, 1910 ... 4,558.81

$\$ 13,282.70$

W. P. Durfee,

W. H. Metzler,

IrHACA, N. Y., December 16, 1911. Auditing Committee.

\section{REPORT OF THE LIBRARIAN FOR THE YEAR 1911}

The last complete Catalogue of the Library was issued as a separate pamphlet in January, 1910. Copies may be procured from the Secretary. The Annual Register contains each year a complete list of the Journals in the Library, but of books other than Journals only the accessions for the current year are given. It is hoped to issue the complete Catalogue every fifth year.

The total accessions in 1911 were 363 volumes. Notable among them are a nearly complete set of the Journal de l'Ecole Polytechnique, secured through the good offices of Professor Upton, the Abhandlungen and Sitzungsberichte of the Munich Academy from 1881 to date, the first Series (1879-1887) and the early 
volumes of the second Series of the Transactions of the Mathematical Society of Kharkoff, and the first two published volumes of the new edition of Euler's Works. The Society will receive in the course of time the full set of Euler's Works, toward the publication of which it has contributed the sum of 5,000 francs. Several lacunae in our sets of Journals have been filled, and others will receive early attention.

The cost of binding the books has heretofore been largely borne by the Columbia University Library under the agreement made in 1901. With the present year the Society has decided to assume the total cost of binding. This will mean an additional expense of about $\$ 75$ per year.

The table below shows the growth of the Library during the past ten years.

\section{David Eugene Smith,} Librarian.

NEW YoRK, December 26, 1911.

\begin{tabular}{l|c|c|c}
\hline & $\begin{array}{c}\text { January 1, } \\
1902 .\end{array}$ & $\begin{array}{c}\text { January 1, } \\
1907 .\end{array}$ & $\begin{array}{c}\text { January 1, } \\
1912 .\end{array}$ \\
\cline { 2 - 4 } & 32 & 1,941 & 2,984 \\
Volumes of periodicals.................. & 89 & $608^{*}$ & $887^{*}$ \\
Volumes, non-periodical............. & 69 & 167 & 180 \\
\hline Periodicals on exchange list ......... & 64 &
\end{tabular}

* Exclusive of unbound dissertations.

\section{LIBRARY RULES}

1. Applications for books may be made in person, or by letter addressed to the American Mathematical Societr, 501 West 116th Street, New York. Members may, if they desire, apply in person directly to the superintendent of the loaning department of the Columbia University Library, where the Society's library is deposited. Books will be delivered directly to those applying in person, and will be sent to other applicants by express at the expense of the borrowers.

2. A book may be kept four weeks from the date of leaving the library, but the loan may be renewed from time to time by writing to the Society in advance of the day when the book is due.

3. Borrowers should return the books in person or by prepaid express. 